\title{
Effect of temperature on the uptake and metabolism of cyanide by weeping willows
}

\author{
Yu, X.-Z.; Trapp, Stefan; Zhou, P.-H.; Chen, L.
}

Published in:

International Journal of Phytoremediation

Link to article, DOI:

$10.1080 / 15226510701376141$

Publication date:

2007

Link back to DTU Orbit

Citation (APA):

Yu, X-Z., Trapp, S., Zhou, P-H., \& Chen, L. (2007). Effect of temperature on the uptake and metabolism of cyanide by weeping willows. International Journal of Phytoremediation, 9, 243-255.

https://doi.org/10.1080/15226510701376141

\section{General rights}

Copyright and moral rights for the publications made accessible in the public portal are retained by the authors and/or other copyright owners and it is a condition of accessing publications that users recognise and abide by the legal requirements associated with these rights.

- Users may download and print one copy of any publication from the public portal for the purpose of private study or research.

- You may not further distribute the material or use it for any profit-making activity or commercial gain

- You may freely distribute the URL identifying the publication in the public portal

If you believe that this document breaches copyright please contact us providing details, and we will remove access to the work immediately and investigate your claim 
THE EFFECT OF TEMPERATURE ON UPTAKE AND METABOLISM OF

\section{CYANIDE BY WEEPING WILLOWS}

\section{Xiao-Zhang Yu **}

Department of Environmental Science, Hunan Agricultural University, Changsha 410128 Hunan, P. R.

China

\section{Stefan Trapp*}

Institute of Environment \& Resources DTU, Technical University of Denmark, DK-2800 Kgs. Lyngby,

Denmark

Pu-Hua Zhou and Liang Chen

Department of Environmental Science, Hunan Agricultural University, Changsha 410128 Hunan, P. R.

China

* European contact, e-mail stt@er.dtu.dk; tel +45 4525 1622, fax +45 45932850

** Asian contact, e-mail yuxiaozhang@hotmail.com; tel +86 7314638287

Running title: Phytoremediation of cyanide 


\section{ABSTRACT}

The response of cyanide uptake and metabolism by plants to changes in temperature was investigated. Pre-rooted weeping willows (Salix babylonica L.) were exposed to hydroponic solution spiked with potassium cyanide for 2 to 3 days. Ten different temperatures were used ranging from $11{ }^{\circ} \mathrm{C}$ to $32{ }^{\circ} \mathrm{C}$. Cyanide in water, plant tissue and air was analyzed spectrophotometrically. The results revealed that significant amounts of the applied cyanide were removed from the aqueous solutions in the presence of plants. Small amounts of free cyanide were detected in plant materials in all treatments, but there was no clear trend to increase or decrease of accumulation in plant material with temperature. The highest cyanide metabolism rate for weeping willows was found at $32{ }^{\circ} \mathrm{C}$ with a value of $2.78 \mathrm{mg} \mathrm{CN} /(\mathrm{kg} \cdot \mathrm{d})$, whereas the lowest value was $1.20 \mathrm{mg} \mathrm{CN} /(\mathrm{kg} \cdot \mathrm{d})$ at $11{ }^{\circ} \mathrm{C}$. The temperature coefficient, $\mathrm{Q}_{10}$, which is the ratio of metabolism rates at a ten ${ }^{\circ} \mathrm{C}$ difference, was determined for weeping willows to be 1.46 . In conclusion, changes in temperature have a substantial influence on the uptake and metabolism of cyanide by plants, but cyanide accumulation does not increase with temperature.

KEY WORDS: Cyanide, Metabolism, Phytoremediation, Temperature, Weeping willows 


\section{INTRODUCTION}

Free cyanide ( $\mathrm{HCN}$ or $\left.\mathrm{CN}^{-}\right)$is one of the most rapidly killing toxicants (Faust, 1994). Despite this, it is a high volume production chemical with a wide variety of uses. The annual production of cyanide hydrogen $(\mathrm{HCN})$ is 1.4 million metric tons, and cyanide compounds are used in the production of adhesives, computer electronics, fire retardants, cosmetics, dyes, nylon, paints, pharmaceuticals, plexiglas, rocket propellant, road and table salts, and marzipan (Mudder and Botz, 2001). About $13 \%$ of the produced cyanide is used in gold mining for heap leaching, which means an environmentally open use. A couple of disastrous events with cyanide compounds, such as the accidental release of methyl isocyanate in the Union Carbide manufactory in Bhopal December 1984 (Sriramachari and Chandra, 1997), the cyanide spill at Baia Mare, Romania 2000 (Korte et al., 2000, UNEP/OCHA, 2000), repeated cyanide spills from the Ashanti gold fields in Ghana and accidents in China (Anane, 2001; Li and Zhen, 2000) - to mention some - have raised great interest in the environmental fate and in treatment strategies for cyanide compounds.

There are several metabolic pathways for free cyanide (Ebbs, 2004). Vascular plants posses an enzyme that can metabolize free cyanide by the enzyme beta-cyanoalanine synthase, which connects HCN to L-cysteine and produces beta-cyanoalanine (Blumenthal et al., 1968). The final metabolite is asparagine, an important amino acid. The activity of the enzyme beta-cyanoalanine synthase is several orders of magnitude higher than the cyanide produced by the ethylene synthesis (Manning, 1988).

The common feature of all vascular plants to metabolize free cyanide was used for a series of studies to 
uncover the kinetics of the plant detoxification system and the relation to uptake and toxicity. Ebbs et al. (2003) used free and iron complexed cyanide labeled with ${ }^{15} \mathrm{~N}$. It was found that free cyanide was rapidly taken up by plants and subsequently metabolized. There was also evidence for an uptake of ferrocyanide, probably followed by metabolism inside plants. Larsen et al. (2004) tested the toxicity and the metabolism rate of free cyanide in five woody plants. The kinetics showed signs of enzyme-limitation and followed Michaelis-Menten kinetics. The metabolism rate of basket willow was the highest of the tested species, with about $10 \mathrm{mg} \mathrm{CN} /(\mathrm{kg}$ fresh weight $\cdot \mathrm{h})$ for roots. Furthermore, willows were able to take up ferro- and ferricyanide and seemed to metabolize the complex (Larsen and Trapp, 2006).

Studies on toxicity and metabolism of cyanide were furthermore done with Chinese plants. These studies confirmed the cited findings on toxicity (Yu et al., 2005a), but gave also new insights.

Twenty-eight-Chinese plant species from 23 families were tested for their removal capacity to remove cyanide in a closed-bottle test (Yu et al., 2004). All species were found to metabolize cyanide, but with different velocity. Data on the Michaelis-Menten kinetics (half-saturation constant $K_{M}$ and maximal removal rate $v_{\max }$ ) of cyanide removal for 12 plant species out of 9 families was determined using excised leaf tissues (Yu et al., 2005b). Values of $v_{\max }$ and $K_{M}$ were found in a range between 6.68 and $21.91 \mathrm{mg} \mathrm{CN} /(\mathrm{kg} \cdot \mathrm{h})$ and 0.90 to $3.15 \mathrm{mg} \mathrm{CN} / \mathrm{L}$, respectively. The values of all $v_{\max }$ were normally distributed with a mean of $13 \mathrm{mg} \mathrm{CN} /(\mathrm{kg} \cdot \mathrm{h})$.

Bushey et al. (2006a, 2006b) developed a model for the calculation of uptake and metabolism of free 
and iron-complexed cyanide and fitted a parameter set to the experimental results of Ebbs et al. (2003) and additional data. Larsen et al. (2005) developed a mathematical model for the fate of cyanide in plants, considering uptake and Michaelis-Menten removal kinetics. The model predicts a non-linear relationship between external concentration of cyanide and the accumulation in plants: below a certain level, plant enzymes can remove the cyanide. No accumulation and no toxic effects occur. Above a certain threshold (about $20 \mathrm{mg} \mathrm{CN} / \mathrm{L}$ for willows grown in sand), the enzyme system of the plant is overloaded, and accumulation of cyanide followed by toxic effects occurs. This means that the metabolism rate of plants plays a key role in accumulation and toxicity. Removal rates were measured for detached plant materials in the closed-bottle test, but could also be determined by fitting of the model (inverse modeling). It turned out that the results for metabolism from detached, but otherwise intact plant materials gave valid model predictions in this case.

All studies cited above were done at room temperature (between 20 and $25^{\circ} \mathrm{C}$ ). However, temperatures in the environment vary. The fastest growth occurs for most plants between 15 and $30^{\circ} \mathrm{C}$ (Larcher 1995). Temperature affects transpiration, growth and metabolism of plants and therefore both uptake and elimination of pollutants. For phytoremediation projects, low temperatures mean slow growth and slow uptake of chemicals and can therefore prolong the time period required to reach clean-up goals. High temperatures increase transpiration of plants. Contaminants are translocated faster. This may result in higher accumulation of toxicants, followed eventually by phytotoxic effects or an increased risk of contamination for consumers of plant materials. But parallel to the increase in transpiration, metabolism rates may also increase. The eventual accumulation of toxic residues depends therefore critically on the change of transpiration and metabolic rates with temperature. 
The influence of temperature on the cyanide metabolism rate of detached leaves was determined in closed bottles (Yu et al., 2005c). For Chinese elder, the highest cyanide removal rate was found at $30^{\circ} \mathrm{C}$ with a value of $12.6 \mathrm{mg} \mathrm{CN} /(\mathrm{kg} \cdot \mathrm{h})$, which was over 3 -fold higher than at $11{ }^{\circ} \mathrm{C}$. The cyanide removal rate of weeping willow at $32{ }^{\circ} \mathrm{C}(9.72 \mathrm{mg} \mathrm{CN} /(\mathrm{kg} \cdot \mathrm{h}))$ was almost five-times higher than at $11{ }^{\circ} \mathrm{C}(1.97$ $\mathrm{mg} \mathrm{CN} /(\mathrm{kg} \cdot \mathrm{h})$ ). This means that the effect of temperature on cyanide metabolism was more important than the choice of the plant species. In this study, the influence of temperature on uptake, accumulation and metabolism of cyanide by intact weeping willows was investigated. The reasons for the influence of temperature on the metabolism rate are discussed.

\section{MATERIALS AND METHODS}

\section{Trees, transpiration and exposure regimes}

Weeping willow cuttings (Salix babylonica L.) were sampled from nature at the campus of the Hunan Agricultural University, China. Tree cuttings (length $40 \mathrm{~cm}$ ) were removed from a mature single specimen and placed in buckets of tap water at room temperature $\left(15-20{ }^{\circ} \mathrm{C}\right)$ under natural sunlight until new roots and leaves appeared. After two-month growth period, pre-rooted cuttings were transferred to a $250 \mathrm{~mL}$ Erlenmeyer flask filled with approximately $250 \mathrm{~mL}$ of aerated aqueous cyanide solution (deionized oxygen-saturated water). The concentration of spiked solutions was $0.98 \mathrm{mg} \mathrm{CN} / \mathrm{L}( \pm 0.038$ $\mathrm{mg} \mathrm{CN} / \mathrm{L}$ ). The flasks were all sealed with cork stoppers and play dough to prevent escape of water or chemicals, and wrapped with aluminum foil to inhibit algae growth. The flasks were put in a climate chamber with constant temperatures of $11,14,17,20,22,24,26,28,30$ and $32{ }^{\circ} \mathrm{C}$ and a relative 
humidity of $60 \pm 2 \%$ under continuous artificial light. Modified ISO 8692 nutrient solution was used to support tree growth. The $\mathrm{pH}$ of the cyanide solution was adjusted to 6.9 with sodium hydroxide. Six separate flasks containing willows and aqueous cyanide were conducted for each treatment temperature.

One control in four replicates was with plant cuttings, but without cyanide, to compare transpiration to treated trees, and to determine background cyanide concentrations. A second control in two replicates (the flasks were also wrapped with aluminum foil and sealed with cork stoppers) was with cyanide, but without plant cuttings to quantify the effects of loss during handling, by volatilization, hydrolysis and/or degradation by microorganism. The concentration of cyanide in the aqueous solution was measured before the tree cuttings were transferred. Exposure periods were 3 days for the treatments of 11, 14, 17, 20 and $22{ }^{\circ} \mathrm{C}$ and 2 days for $24,26,28,30$ and $32{ }^{\circ} \mathrm{C}$, respectively. At the end of the test, the remaining solution, roots, leaves, top and bottom stem were analyzed for cyanide.

The toxic effect of cyanide solutions was evaluated by measuring transpiration in trees. The transpiration of plants is coupled to photosynthesis, and an inhibition of transpiration is a reliable and rapid hint of toxic effects (Trapp et al., 2000). The transpiration of water was determined from the weight loss of the system (flask with solution and plant) during the experiment and expressed as absolute transpiration $(\mathrm{g} / \mathrm{d})$.

\section{Chemical analysis}

A stock solution with a concentration of $0.92 \mathrm{~g} \mathrm{CN} / \mathrm{L}$ was prepared using potassium cyanide. The concentration of cyanide in the aqueous solution was determined photometrically by a standard method (State Environmental Protection Administration of China, 1989, method number GB 7487-87). One to 
ten milliliter solution of the samples (depending on the expected concentration of cyanide) were pipetted into a $25 \mathrm{~mL}$ colorimetric cylinder, and $1 \%$ sodium hydroxide was added to the mark of $10 \mathrm{~mL}$. Then 5.0 $\mathrm{mL}$ of buffer solution with potassium dihydrogen phosphate and sodium phosphate were added. Quickly $0.2 \mathrm{~mL}$ of chloramine-T solution with the concentration of $1 \%$ (volume/mass) were added. The vessel was closed by a stopper and left standing for 3 to 5 minutes. Five milliliter of the colour reagent (a mixture of isonicotinic acid and 3-methyl-1-phenyl-5-pyrazolone) were added. The sample was diluted with water to $25 \mathrm{~mL}$ and mixed. During the analysis, the colorimetric cylinders were all kept in a water bath with a temperature of $32{ }^{\circ} \mathrm{C}$ for 40 minutes. The absorption of light at $638 \mathrm{~nm}$ was measured in a cell of optical path length of $10 \mathrm{~mm}$ against a water reference.

The standard solution of $0.92 \mathrm{mg} \mathrm{CN} / \mathrm{L}(0.10,0.20,0.50,1.0,2.0$ and $5.0 \mathrm{~mL})$ was pipetted into 7 different colorimetric cylinders $(25 \mathrm{~mL})$, and $1 \%$ sodium hydroxide was added to the mark of $10 \mathrm{~mL}$. The remaining procedure was identical to that described earlier. The data obtained were used to derive the standard curve.

All chemicals used were p.a. grade (per analysis, in China: $>99.5 \%$ purity), except potassium cyanide and nicotinic acid, which were technical grade (92 - 95\% purity); but the stock solution and the standard solution of $\mathrm{KCN}$ used in this test were calibrated by a standard solution of $\mathrm{AgNO}_{3}$, which is also calibrated by a standard solution of $\mathrm{NaCl}$ (State Environmental Protection Administration of China, 1989). The detection limit of this method was determined from blank +3 standard deviations of ten replicates to be $0.004 \mathrm{mg} \mathrm{CN} / \mathrm{L}$ with $10 \mathrm{~mL}$ sample volume. 
The analysis of cyanide in plant tissues was also performed by a standard distillation method (State Environmental Protection Administration of China, 1989, method number GB 7486-87). Five milliliters of $1 \%$ sodium hydroxide was poured into the absorption vessel of the distillation unit. Fresh plant materials (2.0 to $10 \mathrm{~g}$, depending on the harvested weight of plant tissues) was cut into pieces and placed into a $500 \mathrm{~mL}$ round bottom flask, and $100 \mathrm{~mL}$ of distilled water was added. Then $1 \mathrm{ml}$ of zinc acetate with the concentration of $10 \%$ (volume/mass) and $10 \mathrm{~mL}$ of tartaric acid (15\%, volume/mass) were added before heating and mixing. Approximately $50 \mathrm{~mL}$ distilled solution containing cyanide from plant materials were collected, quantitatively transferred to a $50 \mathrm{~mL}$ volumetric flask and made up to the volume with water. The solution was stored below $4{ }^{\circ} \mathrm{C}$ until the concentration of cyanide was determined as described. All samples were analyzed with a maximum hold time of 4 hours.

\section{Cyanide transpired by plants}

Cyanide transpired was measured using a refined test chamber. Treated plants were prepared as described above with the entire $250 \mathrm{~mL}$ Erlenmeyer flask enclosed in a glass chamber $(20 \times 20 \times 50 \mathrm{~cm})$ with air flowing through at $24{ }^{0} \mathrm{C}$. The tube at the outflow of the vessel was connected to a gas trap containing $5 \mathrm{~mL}$ sodium hydroxide of $1 \%$ to trap airborne cyanide. The gas trap tube was wrapped with aluminum foil and changed daily, after which all gas tubes were analyzed for cyanide. The duration of this test was 2 days.

\section{Determination of the removal rate}

In the absence of volatilization, negligible background cyanide in controls with plants, and if loss from 
controls without plants is negligible, all loss from the system can be contributed to removal by plants. The removal velocity $v(\mathrm{mg} \mathrm{CN} /(\mathrm{kg} \cdot \mathrm{d}))$ was calculated from final and initial mass using the formula

$v=\frac{m(t)-m(0)}{\Delta t \times M}$

where $m(t)$ is the mass (mg) of cyanide in solution plus plant (sum of leaves, roots, stem) at time $t$, and $m(0)$ is the mass of cyanide in the solution at the beginning; $\Delta t$ is the time period (d), and $M$ is the mass of the plant $(\mathrm{kg})$.

Determination of the temperature coefficient $\mathbf{Q}_{10}$

The influence of temperature on the removal rate was quantified by calculating the temperature coefficient $Q_{10}$, which is defined as the increase of the metabolic activity over a $10{ }^{\circ} \mathrm{C}$ increase in temperature. The temperature coefficient was derived using the equation of Atkin et al. (2002)

$Q_{10}=10^{\Delta T \times s \text { lope }}$

where $\Delta T$ is $10{ }^{\circ} \mathrm{C}$, and slope is the slope of the linear fit curve of $\log v_{P}$ versus temperature $T$.

\section{Statistical methods}

The students t-test (two-tailed) and the Pearson's product-moment correlation and regression were done 
in excel. The significance of the correlations was judged using tabled values for critical $r$ (degree of freedom is $\mathrm{n}-2$, significance level $\alpha$ was 0.01 or 0.05 ) from Sachs (1992). The partial correlation was used to determine whether a correlation between two variables was due to a common correlation to a third variable, with the equation

$$
r_{x y \cdot z}=\frac{r_{x y}-r_{x z} \times r_{y z}}{\sqrt{\left(1-r_{x z}^{2}\right) \times\left(1-r_{y z}^{2}\right)}}
$$

where $\mathrm{r}_{\mathrm{xy} . \mathrm{i}}$ is the partial correlation coefficient between variables $\mathrm{x}$ and $\mathrm{y}$ under the assumption of a constant variable $\mathrm{z}$, and $\mathrm{r}_{\mathrm{xy}}$ is the bivariate Pearson correlation coefficient between variables $\mathrm{x}$ and $\mathrm{y}$ etc.

\section{RESULTS}

\section{Removal of cyanide from hydroponic solution by willows}

Figure 1 gives the changes of concentrations of cyanide in the hydroponic solutions with weeping willows at different treatment temperatures. In the control with cyanide in the absence of plants, negligible changes of cyanide in the solution (data not shown) were found at all treatment temperature groups over the entire exposure periods. This indicated that the disappearance of cyanide from solutions in flasks with plants could be attributed to the uptake by willows. In all treatments, significant amounts of cyanide in hydroponic solution were removed in the presence of weeping willows. The cyanide in solution fell from $0.98( \pm 0.045)$ to $0.43( \pm 0.042) \mathrm{mg} \mathrm{CN} / \mathrm{L}$ at $11{ }^{\circ} \mathrm{C}$ during the 3 - $\mathrm{d}$ exposure. At the 
highest treatment temperature of $32{ }^{0} \mathrm{C}$, cyanide was reduced from $0.99( \pm 0.032)$ to $0.13( \pm 0.098) \mathrm{mg}$ $\mathrm{CN} / \mathrm{L}$ during two days exposure. Only between 8.7 and $36.3 \%$ of cyanide could be recovered from solution and plant material.

$<$ Figure $1>$

\section{Uptake of cyanide into plants}

Figure $2 \mathrm{a}, \mathrm{b}, \mathrm{c}$ and $\mathrm{d}$ shows the concentrations of cyanide in plant tissues at different treatment temperatures. Cyanide was detected in plant materials in all treatment groups, confirming uptake of cyanide into plants. The cyanide background in unexposed control trees was $0.023 \mathrm{mg} \mathrm{CN} / \mathrm{kg}$ for roots, $0.038 \mathrm{mg} \mathrm{CN} / \mathrm{kg}$ for leaves and $0.015 \mathrm{mg} \mathrm{CN} / \mathrm{kg}$ for stem ( $\mathrm{n}=2$ for all controls), and the concentrations in the respective control solutions were below the detection limit of $0.004 \mathrm{mg} \mathrm{CN} / \mathrm{L}$. Compared to controls, only cyanide levels in roots and bottom stem of exposed plants were elevated. The concentration ratios between plant and initial solution can directly be seen from Figures 2 abcd (because the concentration in initial solution was $0.98 \mathrm{mg} / \mathrm{kg}$, practically 1 ). The concentration ratio between root and initial solution (root concentration factor RCF) is falling with temperature from 11 to $22{ }^{\circ} \mathrm{C}$ (three days exposure) and again from 26 to $32{ }^{\circ} \mathrm{C}$ (two days exposure). The linear trend is significant at $\alpha=$ 0.05. For top and bottom stems (stem concentration factor SCF) as well as for leaves (leaf concentration factor LCF), there is no clear and no significant trend. Related to final concentrations in solution, the RCF decreases with temperature, while SCF and LCF increase, but none of the trends is significant $(\alpha=$ $5 \%)$. 
$<$ Figure 2 a $>$

$<$ Figure 2 b $>$

$<$ Figure 2 c $>$

$<$ Figure 2 d $>$

\section{Mass balance of cyanide}

After uptake from solution and translocation to upper stem and leaves, cyanide may have been volatilized. However, no cyanide above detection limit was trapped for willows exposed to $24{ }^{0} \mathrm{C}$ over a 2-d test period using the test chamber with the gas trap (cyanide transpired at other treatment temperatures was not measured). The same result was also found in the study of Ebbs et al. (2003). Trapp et al. (2001) found small amounts (1.5\%) of cyanide in air. Therefore, cyanide loss into air was neglected in the mass balance given in Table 1, and only cyanide in plant tissues and in the solution was considered. Among the plant materials, the largest amount of cyanide was found in the roots, followed by the bottom stem. The lowest cyanide concentration was found in leaves, where all values were very close to the background in controls $(0.038 \mathrm{mg} / \mathrm{kg})$. The cyanide recovered from plant biomass accounted for maximally $2 \%$ of the initially applied mass. Only between 8.7 and $36.3 \%$ of cyanide could be recovered from final solution and plants. Loss from controls without plants was negligible, so most likely, all loss was due to metabolism by plant enzymes. This is consistent with earlier findings (Ebbs et al., 2003; Larsen et al., 2004, 2005; Yu et al., 2004). The calculated cyanide metabolism rates are shown 
in Table 1. The rates increased with temperature. The highest cyanide metabolism rate was found at 32 ${ }^{0} \mathrm{C}$ with a value of $2.78 \mathrm{mg} \mathrm{CN} /(\mathrm{kg} \cdot \mathrm{d})$, which was more than 2 -fold higher than at $11{ }^{\circ} \mathrm{C}$.

\section{$<$ Table $1>$}

\section{Response of plant transpiration to cyanide exposure at different temperatures}

Figure 3 shows the absolute transpiration of control trees (without exposure to cyanide) compared to exposed trees in the temperature range from $11{ }^{\circ} \mathrm{C}$ to $32{ }^{\circ} \mathrm{C}$. A slight difference in transpiration between treated plants and non-treated plants was found, probably stemming from differences in individual trees. The difference is generally small, and not significant (two-tailed t-test, significance level $\alpha=0.05$ ). In some cases, exposed trees show the higher transpiration. No attempt was made to select homogeneous plant materials, therefore the transpiration is subject to variations. The results also indicate that with the increase of temperature, the transpiration of plants generally increased, as expected. There were also no significant differences in the plant growth between treated and non-treated plants (data not shown). Symptoms of chlorosis of leaves were not observed in any plant, giving rise to the conclusion that the cuttings maintained normal physiological functioning over the entire test period without any measurable and observed toxic effects.

\section{$<$ Figure 3 $>$}




\section{Temperature coefficient $\mathbf{Q}_{10}$}

The response of enzymatic reactions to a temperature increase can be summarized by two functions, an increase of the forward reaction, and a decay due to enzyme denaturation as the temperature rises (Raison, 1980). Figure 4 shows the fit line $\left(r^{2}=0.983\right)$ from which a temperature coefficient $Q_{10}$ of 1.46 was calculated. This value is in the range of previously reported $Q_{10}$-values of 1.1 to 2.9 (Azcón-Bieto, 1992; Atkin et al., 2000) for metabolic processes.

$<$ Figure 4>

\section{DISCUSSION}

The removal rates from this study can be compared to rates found earlier, but which were derived from removal tests in closed bottles. Yu et al. (2004) found for weeping willow Salix babylonica L. a removal capacity of $6.08 \mathrm{mg} \mathrm{CN} /(\mathrm{kg} \cdot \mathrm{h})$ with an initial concentration in solution of $0.94 \mathrm{mg} \mathrm{CN} / \mathrm{L}$ in the test with detached leaves in a closed bottle. The same test was performed with varying concentrations in solution (0.49; $1 ; 2.07 ; 7.59 \mathrm{mg} \mathrm{CN} / \mathrm{L})$ to determine the Michaelis-Menten parameters (Yu et al. 2005b). For Salix babylonica L., the removal rate at $1.0 \mathrm{mg} \mathrm{CN} / \mathrm{L}$ was $4.1 \mathrm{mg} \mathrm{CN} /(\mathrm{kg} \cdot \mathrm{h})$, while $v_{\max }$ was 9.57 to 12.76 mg CN/(kg.h). Larsen et al. (2004) found for the closely related species basket willow (Salix viminalis) $v_{\max }$ for leaves from 9.3 to $9.4 \mathrm{mg} \mathrm{CN} /(\mathrm{kg} \cdot \mathrm{h})$ and for roots from 10.7 to $14.5 \mathrm{mg} \mathrm{CN} /(\mathrm{kg} \cdot \mathrm{h})$. In later experiments, Larsen et al. (2005) found a $v_{\max }$ for basket willow leaves of $9.6 \mathrm{mg} \mathrm{CN} /(\mathrm{kg} \cdot \mathrm{h})$ and for 
roots of $6.9 \mathrm{mg} \mathrm{CN} /(\mathrm{kg} \cdot \mathrm{h})$.

To compare these earlier results from closed-bottle tests with the results obtained here with intact trees, it has to be considered that the plant mass in contact with solution is different. Typical willow cuttings have approximately 1 to $2 \mathrm{~g}$ roots, 35 to $40 \mathrm{~g}$ stem and 1 to $2 \mathrm{~g}$ leaves. The ratio of root to total plant mass is therefore approximately 1:20 to $1: 40$, and a 20 to 40 times faster removal rate can be expected with detached plant material in the closed-bottle test.

For $22{ }^{0} \mathrm{C}$, a rate of $1.97 \mathrm{mg} \mathrm{CN} /(\mathrm{kg} \cdot \mathrm{d})$ was obtained here. Multiplied by factor 40 gives a rate of 78.7 $\mathrm{mg} \mathrm{CN} /(\mathrm{kg} \cdot \mathrm{d})$ or $3.3 \mathrm{mg} \mathrm{CN} /(\mathrm{kg} \cdot \mathrm{h})$. A rate of $3.3 \mathrm{mg} \mathrm{CN} /(\mathrm{kg} \cdot \mathrm{h})$ at $22{ }^{0} \mathrm{C}$ and of $3.4 \mathrm{mg} \mathrm{CN} /(\mathrm{kg} \cdot \mathrm{h})$ at 24 ${ }^{0} \mathrm{C}$, which is obtained if only root mass is considered, is in fair agreement to the earlier obtained result of $4.1 \mathrm{mg} \mathrm{CN} /(\mathrm{kg} \cdot \mathrm{h})$ for weeping willow leaves at room temperature $\left(23{ }^{0} \mathrm{C}\right)$ and the same initial concentration (Yu et al., 2004). Furthermore, the rate determined here does not correspond to the maximal removal rate $\mathrm{v}_{\max }$, which would be obtained at higher initial concentrations or by a non-linear fit to results from varying concentrations.

In our previous work, the influence of temperature on the removal of cyanide by weeping willow leaves in closed bottles was studied. In the temperature range from 11 to $32{ }^{0} \mathrm{C}$, a value for $Q_{10}$ of 2.09 was found (Yu et al., 2005c). This increase of cyanide removal with temperature could be explained half by an increase of the transport kinetics (due to a lower cuticle permeability at higher temperature), and half by an increase of the activity of the enzymes that metabolize cyanide.

In the study here, experiments were done with intact trees, and the uptake of cyanide was by roots. The $Q_{10}$ value obtained is lower, only 1.46 . The variation in temperature affected both the kinetics of loss from solution and the transpiration. Subsequently, the observed change of the loss of cyanide with 
temperature could either be due to an increased uptake of the compound into root cells (with transpiration water or by diffusion), or due to an increase of the activity of the metabolizing enzymes. The $\log$-linear correlation between metabolic rate $\log v_{p}$ and temperature is highly significant (Figure 4, $\left.r^{2}=0.983\right)$. The correlation between temperature and transpiration is weaker $\left(r^{2}=0.60\right)$, but still highly significant $(\alpha<0.01)$. Since humidity and light were kept constant during the experiments, an even better correlation might be expected, but the size of the individual trees varied and had some influence on the correlation between temperature and transpiration. The correlation between transpiration and cyanide loss from the system (assumed to be metabolism) is also significant $\left(\mathrm{r}^{2}=0.52\right.$, significant at $\alpha=$ 0.05). But a partial correlation between temperature, metabolism and transpiration unveils that the correlation between temperature and metabolic rate, assuming constant transpiration, would still be 0.96 . On the other hand, the partial correlation between metabolism and transpiration (assuming constant temperature) is not significant $(\alpha=0.05)$. It can be concluded that the transpiration as such had no direct influence on the loss of cyanide from solution. Indeed, it was found earlier that the removal of leaves, which stops transpiration almost completely, did not change the removal of cyanide from solution, compared to intact trees (Larsen et al., 2005). This indicates that cyanide uptake into roots was mainly by diffusion and independent of the uptake of water. However, a temperature increase from $11{ }^{0} \mathrm{C}$ to 32 ${ }^{0} \mathrm{C}$ means, according to the Einstein relation (Barrow, 1980), an increase of the diffusion coefficient of only $6.7 \%$. Therefore we cannot explain the increase in loss with temperature, which we found in this experiment, with the faster diffusion of the molecules into roots, except if the permeability of the roots would increase very much with increasing temperature. Subsequently remains as most plausible reason for the increased loss at higher temperature a higher activity of cyanide-metabolizing enzymes at higher temperature. 


\section{CONCLUSIONS}

The results of this laboratory study have demonstrated that a large fraction of cyanide was readily taken up and metabolized by weeping willows from the hydroponic solution at all treatment temperatures. Only small amounts of the applied cyanide were recovered from plant tissue. The temperature coefficient, $Q_{10}$, which is the ratio of metabolism rates at a $10{ }^{\circ} \mathrm{C}$ difference, was determined for intact weeping willows to be 1.46 . The most likely reason for the increase of cyanide removal from solution with increasing temperature was an increase of the activity of the metabolizing enzymes. The increase in metabolism was higher than the increase in transpiration. Therefore, no increased accumulation of cyanide and no increase of toxicity with increasing temperature was found in the temperature range considered here.

\section{ACKNOWLEDGEMENTS}

This work was supported by the Hunan Agricultural University (Grant No: 03YJ05). Thanks to Yawen

Tang and Yongmiao Yang for their engaged help. 


\section{REFERENCES}

Anane, M. Environmental News 6 Nov 2001.

(Nov 2001 at http://ens-news.com/ens/oct2001/20011\%2D10\%2D24\%2D01.html)

Atkin, O.K., Evans, J., Ball, M., Lambers, H., and Pons, T. 2000. Leaf respiration of snow gum in the light and dark: interactions between temperature and irradiance. Plant Physiol. 122, 915-923.

Atkin, O.K., Zhang, Q., and Wiskich J. 2002. Effect of temperature on rates of alternative and cytochrome pathway respiration and their relationship with the redox poise of the Quinone pool. Plant Physiol. 128, 212-222.

Azcón-Bieto, J. 1992. Relationships between photosynthesis and respiration in the dark in plants. In: Trends in Photosynthesis Research, pp. 241-253 (Barber, J., Guerrero, M.G., and Medrano, H., Eds.), Intercept Ltd, Andover.

Barrow GM (1980): Physical chemistry part III. Bohmann, Vienna, 3rd ed (in German).

Blumenthal, S., Hendrickson, H.R., Abrol, Y.O., and Conn, E.E. 1968. Cyanide metabolism in higher plants. III. The biosynthesis of $\beta$-cyanoalanine. J. Biol. Chem. 243, 5302-5307.

Bushey, J.T., Ebbs, S.D. and Dzombak, D. 2006a. Development of a plant uptake model for cyanide. Int. 
J. Phytorem. 8, 25-43.

Bushey, J.T., Small, M., Dzombak, D., and Ebbs S.D. 2006b. Parameter estimation of a plant uptake model for cyanide: application to hydroponic data. Int. J. Phytorem. 8, 45-62.

Ebbs, S., Bushey, J., Poston, S., Kosma, D., Samiotakis, M., and Dzombak D. 2003. Transport and metabolism of free cyanide and iron cyanide complexes by willow. Plant Cell Environ. 26, 1467-1478.

Faust, R.A., Toxicity Summary for Cyanide. Report to the Oak Ridge Laboratorium, Tennessee, US, 1994. October 2001 at http://risk.1sd.ornl.gov/tox/profiles/cyanide_f_V1.shtml

Korte, F., Spiteller, M., and Coulston, F. 2000. The cyanide leaching gold recovery process is a non-sustainable technology with unacceptable impacts on ecosystems and humans: the disaster in Romania. Ecotox. Environ. Safet. 46, 241-245.

Larcher, W. 1995. Physiological plant ecology. Springer, Berlin, $3^{\text {rd }}$ ed.

Larsen, M., Trapp, S., and Pirandello, A. 2004. Removal of cyanide by woody plants. Chemosph. 54, $325-333$.

Larsen, M., Ucisik, A., and Trapp, S. 2005. Uptake, metabolism, accumulation and toxicity of cyanide in willow trees. Environ. Sci. Technol. 39, 2135-2142. 
Larsen, M. and Trapp, S. 2006. Uptake of iron cyanide complexes into willow trees. Environ. Sci. Technol. 40, 1956-1961.

Li, S. H. and Zhen, B. S. 2000. Natural degradation and environmental impact of cyanide from a gold mine. Environmental Science 3, 110-112 (in Chinese).

Manning, K. 1988. Detoxification of cyanide by plants and hormone action. In: Cyanide compounds in biology, pp. 92-110 (Ciba Foundation Eds.). John Wiley \& Sons, Chichester, UK.

Mudder, T. and Botz, M. 2001. A guide to cyanide. Mining Environ. Manag. 9, 8-12.

Raison, J.K. 1980. Effect of low temperature on respiration. In: The biochemistry of plants, Vol 2: Metabolism and respiration, pp. 613-626 (D. Davis., Ed.). Academic Press, New York, USA.

Sachs L. 1992. Angewandte Statistik (Applied statistics). Springer, Berlin, 7th ed.

Sriramachari, S. and Chandra, H. 1997. The lessons of Bhopal (toxic) MIC gas disaster. Chemosph. 34, $2237-2250$.

State Environmental Protection Administration of China (SEPA), 1989. Analysis method for water and wastewater. Beijing: Environmental Science Press, China, 145-154, 3rd ed. (In Chinese). 
Trapp, S., Zambrano, K.C., Kusk K.O., and Karlson, U. 2000. A phytotoxicity test using transpiration of willows. Arch. Environ. Contam. Toxicol. 39, 154-160.

Trapp, S., Larsen, M., and Christiansen, H. 2001. Experimente zum Verbleib von Cyanid nach Aufnahme in Pflanzen. UWSF-Z.Umweltchem.Ökotox. 13, 29-37.

UNEP/OCHA United Nations Environmental Program and Office for the Co-ordination of Humanitarian Affairs, 2000. Cyanide spill at Baia Mare, Romania. Report September 2000 at http://www.natural-resources.org/environment/BaiaMare/

Yu, X.Z., Trapp, S., Zhou, P.H., Wang, C., and Zhou, X.S. 2004. Metabolism of cyanide by Chinese vegetation. Chemosph. 56, 121-126.

Yu, X.Z., Trapp, S., and Zhou, P.H. 2005a. Phytotoxicity of cyanide to weeping willow trees. Environ. Sci. Pollut. Res. 12, 109-113.

Yu, X.Z., Zhou, P.H., Zhou, X.S., and Liu, Y.D. 2005b. Cyanide removal by Chinese vegetation. Quantification of the Michaelis-Menten kinetics. Environ Sci. Pollut. Res. 12, 227-232.

Yu, X.Z., Trapp, S., Zhou, P.H., and Hu. H. 2005c. The effect of temperature on the rates of cyanide metabolism of two woody plants. Chemosph. 59, 1099-1104. 


\section{Tables and captions}

Table 1 Cyanide mass balance. Values are the mean of six replicates (in parenthesis: standard deviation).

The exposure period was 3 days for the treatments from $11{ }^{0} \mathrm{C}$ to $22{ }^{0} \mathrm{C}$ and 2 days for the treatments from $24{ }^{0} \mathrm{C}$ to $32{ }^{0} \mathrm{C}$.

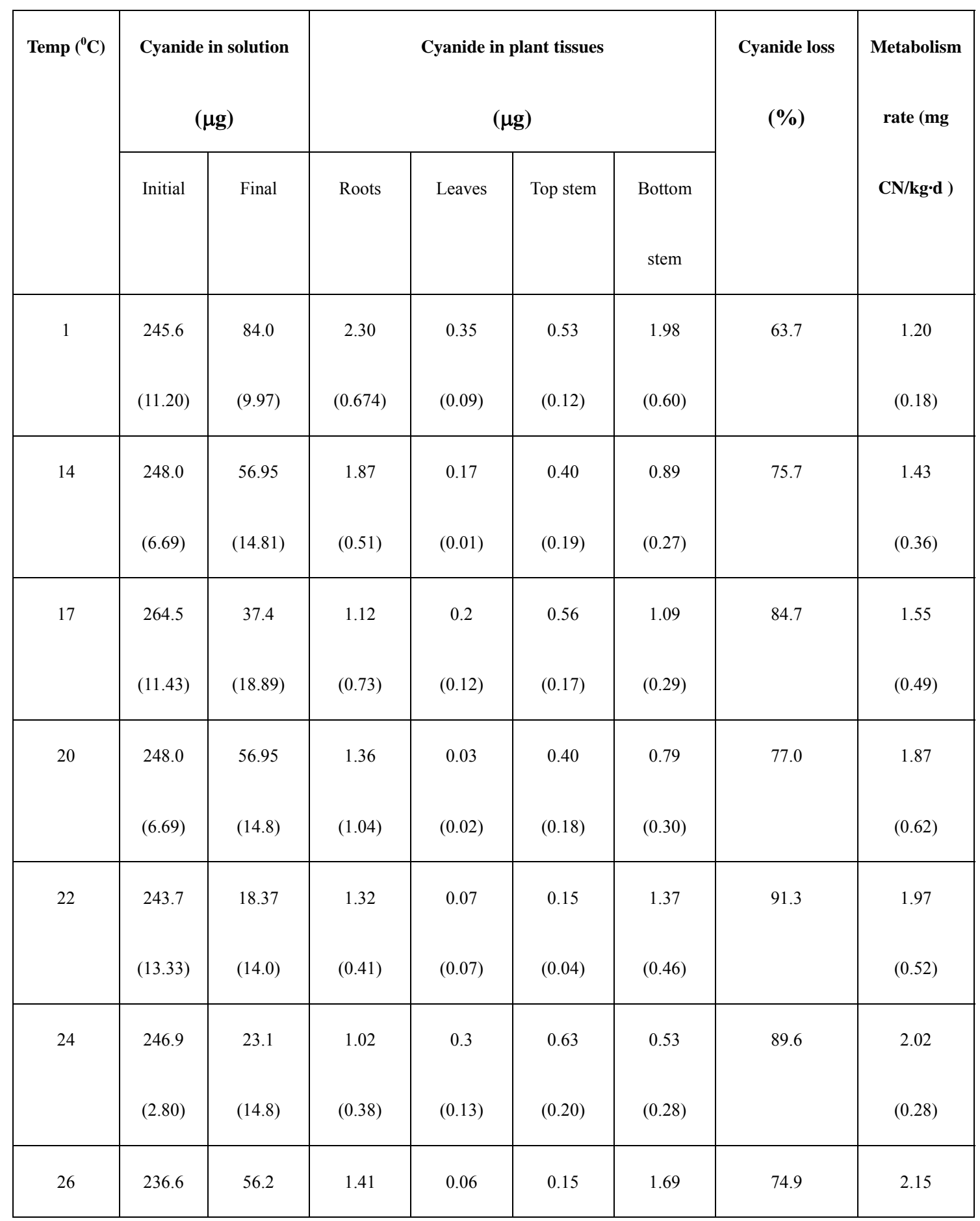




\begin{tabular}{|c|c|c|c|c|c|c|c|c|}
\hline & $(3.65)$ & $(8.65)$ & $(0.19)$ & $(0.02)$ & $(0.03)$ & $(0.60)$ & & $(0.35)$ \\
\hline 28 & 236.6 & 56.2 & 1.19 & 0.06 & 0.22 & 0.69 & 78.4 & 2.27 \\
& $(3.65)$ & $(8.65)$ & $(0.53)$ & $(0.02)$ & $(0.06)$ & $(0.07)$ & & $(0.38)$ \\
30 & 239.5 & 45.2 & 0.92 & 0.21 & 0.59 & 1.37 & 79.8 & 2.62 \\
& $(6.16)$ & $(19.12)$ & $(0.11)$ & $(0.07)$ & $(0.24)$ & $(0.36)$ & & $(0.96)$ \\
\hline 32 & 246.9 & 23.7 & 0.82 & 0.35 & 0.33 & 0.86 & 89.4 & 2.78 \\
& $(8.06)$ & $(18.1)$ & $(0.26)$ & $(0.15)$ & $(0.14)$ & $(0.37)$ & & $(0.95)$ \\
\hline
\end{tabular}




\section{Figures and captions}

Figure 1 Measured cyanide concentration $(\mathrm{mg} \mathrm{CN} / \mathrm{L})$ in aqueous solution at different treatment temperatures. The exposure period was 3 days for the treatments from $11{ }^{0} \mathrm{C}$ to $22{ }^{0} \mathrm{C}$ and 2 days for the treatments from $24{ }^{0} \mathrm{C}$ to $32{ }^{0} \mathrm{C}$. The values are the mean of six replicates for samples. Error bars represent standard deviation.

Figure 2 Measured cyanide concentrations ( $\mathrm{mg} \mathrm{CN} / \mathrm{kg}$ fresh weight) in a) roots, b) leaf, c) top stem and d) bottom stem of weeping willows (Salix babylonica L.) at different treatment temperatures. The exposure period was 3 days for the treatments from $11{ }^{\circ} \mathrm{C}$ to $22{ }^{\circ} \mathrm{C}$ and 2 days for the treatments from 24 ${ }^{0} \mathrm{C}$ to $32{ }^{\circ} \mathrm{C}$. The values are the mean of six replicates. Error bars represent standard deviation; FW = fresh weight.

Figure 3 Measured absolute transpiration (g/d) of weeping willows (Salix babylonica L.) at different treatment temperatures. The values are the mean of six replicates for treated plants and four replicates for untreated plants. Error bar represent standard deviation.

Figure $4 \log _{10}$ of cyanide metabolism rate $v_{p}$ (mean of six replicates) vs. treatment temperature; trendline represents linear regression. 


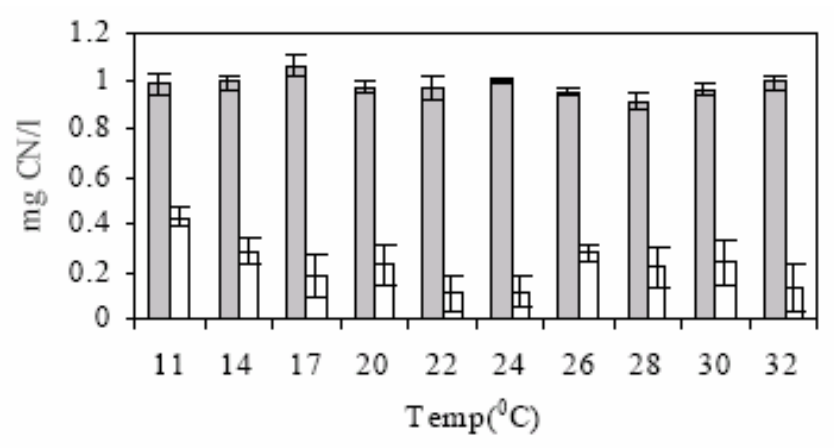

$\square$ Initial Conc. $\square$ Final Conc.

Figure 1 Xiaozhang YU

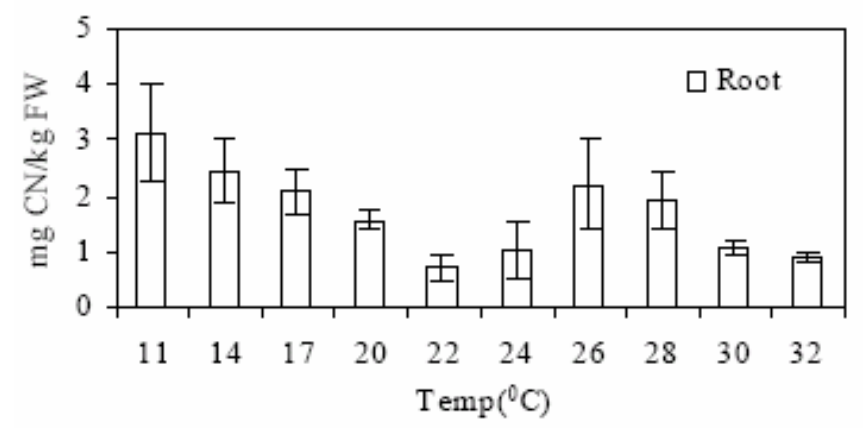

Figure 2a Xiaozhang YU

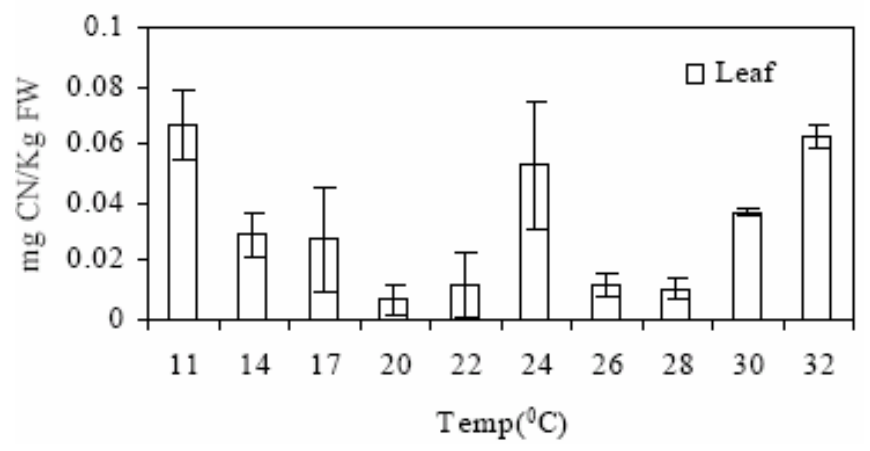

Figure 2b Xiaozhang YU 


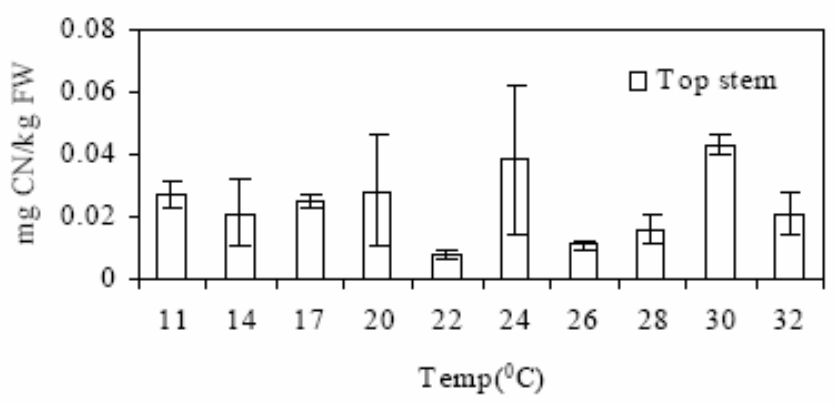

Figure 2c Xiaozhang YU

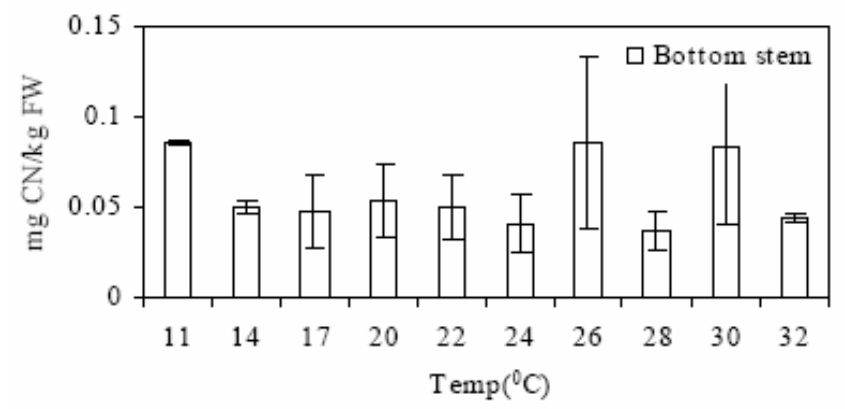

Figure 2d Xiaozhang YU

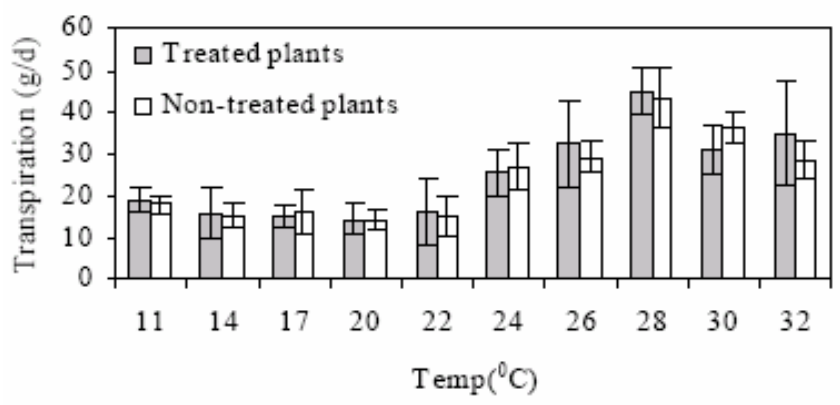

Figure 3 Xiaozhang YU 


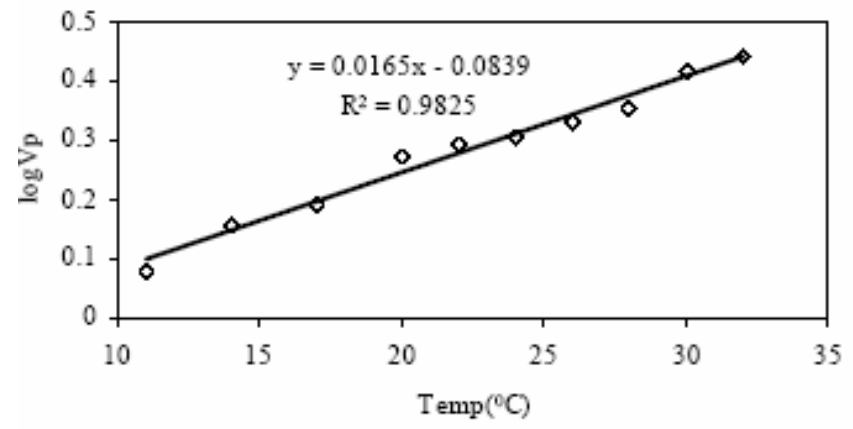

Figure 4 Xiaozhang YU 